\title{
Degradation capability of the coastal environment adjacent to the Itata River in central Chile $\left(36.5^{\circ} \mathrm{S}\right)$
}

\author{
S. Pantoja ${ }^{1,2}$, M. H. Gutiérrez ${ }^{1}$, P. Ampuero ${ }^{3}$, and E. Tejos ${ }^{2}$ \\ ${ }^{1}$ Department of Oceanography and Center for Oceanographic Research in the eastern South Pacific (COPAS), \\ University of Concepcion, Concepcion, Chile \\ ${ }^{2}$ Program of Marine Research of Excellence (PIMEX-Nueva Aldea), School of Natural and Oceanographic Sciences, \\ University of Concepcion, Concepcion, Chile \\ ${ }^{3}$ Graduate Program in Oceanography, Department of Oceanography, University of Concepcion, Concepcion, Chile
}

Received: 21 January 2011 - Published in Biogeosciences Discuss.: 11 February 2011

Revised: 21 July 2011 - Accepted: 22 July 2011 - Published: 3 August 2011

\begin{abstract}
The response of the coastal ocean influenced by both river discharges and inputs of photosynthetically derived organic carbon product of upwelling, was evaluated by estimating rates of microbial hydrolysis of macromolecules with the goal of estimating the potential degradation capability of the coastal ecosystem off central Chile. Extracellular enzymatic activity (EEA) in seawater was dominated by aminopeptidase activity on substrate L-leucine-4-methyl7-coumarinylamide (MCA-leu) (1.2 to $182 \mathrm{nmoll}^{-1} \mathrm{~h}^{-1}$ ) followed by 4-methylumbelliferyl-ß-D-glucoside (MUFglu) $\left(0.08-61 \mathrm{nmoll}^{-1} \mathrm{~h}^{-1}\right)$ and 4-methylumbelliferyl- $\beta-\mathrm{D}$ cellobiose (MUF-cel) $\left(0.15-7 \mathrm{nmol}^{-1} \mathrm{~h}^{-1}\right)$, with the highest rates measured during spring-summer. In riverine waters, extracellular enzymatic hydrolysis remained within the range of 45 to $131 \mathrm{nmoll}^{-1} \mathrm{~h}^{-1}$ for MCA-leu and ca. $20 \mathrm{nmoll}^{-1} \mathrm{~h}^{-1}$ for glucosidic substrates, year-round. Contrary to the EEA observed for the marine water column, surface sediment extracellular enzymatic hydrolysis of MCA-leu (0.04 to $6.13 \mathrm{nmol} \mathrm{g}^{-1} \mathrm{dwh}^{-1}$ ) was in the same order of magnitude as the rates observed for MUFcel $\left(0.004\right.$ to $\left.5.1 \mathrm{nmol} \mathrm{g}^{-1} \mathrm{dw} \mathrm{h}^{-1}\right)$ and MUF-glu (0.007 to $10.5 \mathrm{nmol} \mathrm{g}^{-1} \mathrm{dw} \mathrm{h}^{-1}$ ). Moreover, hydrolysis in sediments was characterized by higher rates during winter compared with spring-summer in the coastal and estuarine zone. The five years of data allowed us to evaluate the potential capability of microbial processing of organic carbon in the coastal area adjacent to the Itata river discharge where the increase in primary production in the productive seasons is accompanied by the increase in hydrolysis of macromolecules.
\end{abstract}

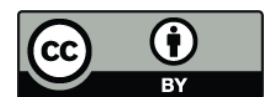

Correspondence to: S. Pantoja (spantoja@udec.cl)

\section{Introduction}

Although continental shelves (global area $26 \times 10^{12} \mathrm{~m}^{2}$ ) sustain high primary production, and estuaries (global area $1.05 \times 10^{12} \mathrm{~m}^{2}$ ) are reservoirs of terrestrial primary production transported by rivers, both constitute a small fraction of the global ocean (7.5\%, Cai et al., 2011. Several studies have shown that continental shelves sequester more than $40 \%$ of oceanic carbon (Hedges and Keil, 1995; Muller-Karger et al., 2005), however, there are uncertainties as to our ability to quantify the exchange of carbon between marine and terrestrial systems (Liu et al., 2000), and difficulties in evaluating the main processes controlling the fate of terrigenous carbon in coastal waters and sediments (Hedges and Keil, 1995). These knowledge gaps have impeded us from determining why most of the terrestrial carbon (ca. $0.25 \mathrm{Pg}$ ) transported to the ocean by world rivers every year (Cauwet, 2002) disappears from the reservoir of dissolved organic matter in the ocean (Hedges and Parker, 1976) and marine sediments (Hedges, 2002). Considering the refractory nature of terrestrial carbon (Hedges, 1992), Hedges and Keil (1995) posed the conundrum of the relatively short residence time of terrestrial organic matter compared with the seemingly labile plankton-derived marine organic molecules, pointing to the role of the coastal ocean in processing organic matter (Rabouille et al., 2001).

In coastal upwelling ecosystems, the biological community thrives in an environment of high availability of organic molecules derived from high primary production rates, thus enhancing microbial secondary production (e.g., Quiñones et al., 2010). The coastal ocean in the Humboldt Current System off central Chile at $36.5^{\circ} \mathrm{S}$ (Fig. 1) is under the influence of seasonal upwelling and associated productivity

Published by Copernicus Publications on behalf of the European Geosciences Union. 


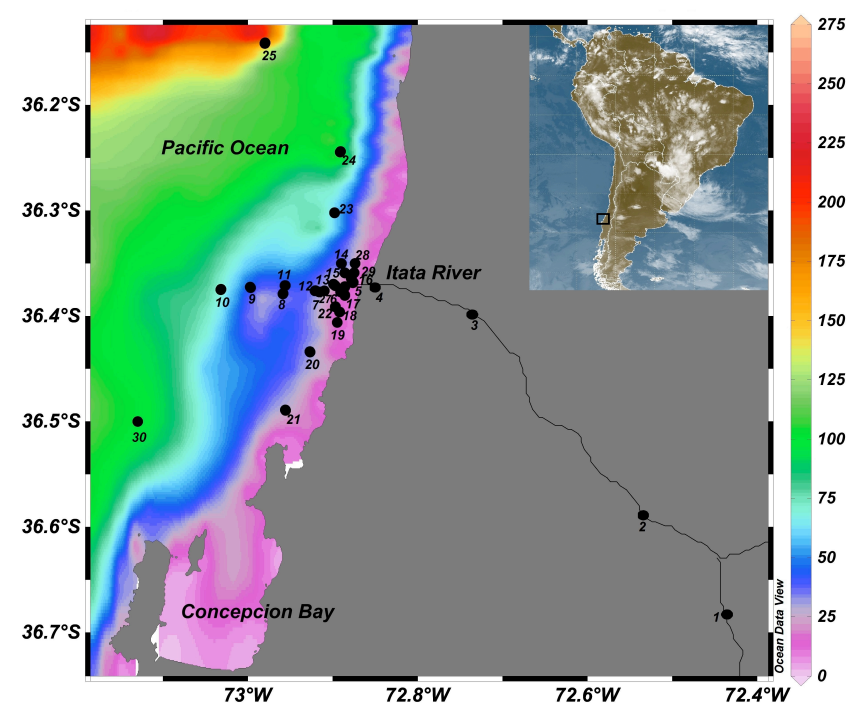

Fig. 1. Study area and location of the sampling stations in the coastal ocean adjacent to the Itata River off Central Chile. Map generated using the software Ocean Data View (Schlitzer, 2010). Color scale in the ocean represents depth in meters as shown in the bar to the right.

cycles (Daneri et al., 2000). In this area, coastal upwelling interacts with two seasonal physical processes that modify vertical stratification: the heat balance in the mixed layer during the austral summer, and the fresh water balance during the austral winter due to greater freshwater discharges from the Bio-Bío and Itata rivers (Sobarzo et al., 2007). The interplay of upwelling and freshwater discharge has a noticeable effect on the chemistry and biology of the water column. For instance, at a site $30 \mathrm{~km}$ offshore, we observed that biogenic opal from diatom productivity dominates the water column during summer, whereas lithogenic opal predominates during austral winter (Sánchez et al., 2008).

It has been observed that microbial heterotrophic activity is enhanced by the input of organic matter by both phytoplankton production and riverine sources, thus explaining the enhanced microbial consumption rates at the boundaries between river and oceanic waters (Albright, 1983; Kirchman et al., 1989). Only a small fraction of the organic matter pool are monomers capable of being directly transferred to microorganisms for remineralization, thus efficient hydrolysis and utilization of autochthonous and allochthonous biopolymers, such as proteins and carbohydrates, are crucial for sustaining high microbial growth rates and associated degradation of organic matter (Azam, 1998). The extracellular enzymes of aquatic microbes (Chróst, 1991) are key components in the hydrolysis of abundant marine biopolymers. Extracellular hydrolysis is the initial step in carbon mineralization in which organic macromolecules are broken down into smaller substrates capable of being incorporated across the cell membrane of microorganisms (e.g. King, 1986; Chróst,
1991; Hoppe, 1991; Pantoja et al., 1997; Arnosti, 2003), thereby affecting the fate of organic matter in the marine environment (Arnosti, 2011).

In this paper, we undertook the study of the temporal and spatial varibility of extracellular enzymatic hydrolysis of carbohydrates and proteins, as a proxy of microbial reworking in the coastal upwelling ecosystem adjacent to the Itata River in central Chile (Fig. 1). We used fluorogenic molecules MUFglu, MUF-cel and MCA-Leu to represent substrates of different reactivity and different models of extracellular enzymes (glucosidase, glucanase, and aminopeptidase, respectively). Thus, we represented the labile marine organic matter as the protein model molecule MCA-leu, and the more refractory pool of organic matter associated to river input as the cellulose model molecules MUF-glu and MUF-cel.

We aim to obtaining a deeper understanding of the degradation capability of this coastal area in relation to carbon availability for heterotrophic consumption. An accurate insight into the magnitude of organic matter reworking of the coastal ocean is needed to understand how the coastal ocean could respond to natural and anthropogenic perturbations (Ver et al., 1999; Rabouille et al., 2001).

\section{Materials and methods}

\subsection{Study area}

We studied the coastal zone off central-southern Chile (ca. $36.5^{\circ} \mathrm{S}$ ) under the direct influence of the Humboldt Current System (Strub et al., 1998). One of the main features of this coastal system is the occurrence of fertilization events due to upwelling of sub-surface nutrient-rich waters into the photic zone during the austral spring-summer (e.g. Ahumada and Chuecas, 1979, which promotes very high primary production rates (Daneri et al., 2000; Montero et al., 2007), and significant commercial fish landings (Quiñones et al., 2010). Upwelling waters also carry low oxygen concentrations thus generating a seasonal suboxic layer below $20 \mathrm{~m}$ water depth (Sobarzo et al., 2007).

The thermal structure of the water column during spring and summer is controlled by solar radiation in the top 10 $\mathrm{m}$ and upwelling favorable wind stress below $15 \mathrm{~m}$ depth, resulting in a stratified surface layer and lower temperature waters under the thermocline. During winter, haline stratification is observed in the top layer due to precipitation, enhanced freshwater discharge from the Bio-Bío and Itata rivers, and downwelling below the thermocline induced by northerly winds (Sobarzo et al., 2007). The coastal ocean receives a noticeable amount of terrigenous material from the adjacent rivers, evidenced by the dominance of lithogenic over biogenic opal during the austral winter (Sánchez et al., 2008) and the presence of lignin phenols in coastal sediments (Schubert et al., 2000). 
Observations were carried out in the marine and riverine environments of Central Chile encompassing latitudes from $36^{\circ} 10^{\prime} \mathrm{S}$ to $36^{\circ} 7^{\prime} \mathrm{S}$ and from $73^{\circ} 10^{\prime} \mathrm{W}$ to $72^{\circ} 40^{\prime} \mathrm{W}$ surrounding the Itata river mouth and as far as $20 \mathrm{NM}(37 \mathrm{~km})$ from the coast (Fig. 1). Sampling covered coastal areas under direct influence of the river discharge and under a strong seasonal regime of upwelling and marine productivity. The Itata River runs for ca. $195 \mathrm{~km}$ and its water mass transport at the mouth is, on average, $240 \mathrm{~m}^{3} \mathrm{~s}^{-1}$ (Dussaillant, 2009). During December 2009, the submarine outfall disposal for residues from the waste treatment plant of a major pulp mill was installed in December 2009. The pipe is $2 \mathrm{~km}$ long, and is located at $30 \mathrm{~m}$ depth near sampling station 6 (Fig. 1).

\subsection{Water and sediment sampling}

We carried out 26 sampling campaigns between 2006 and 2010 covering 16 field observations during the austral springsummer and 10 in autumn-winter (Table 1) onboard the research vessel Kay-Kay II (University of Concepción) and small boats for estuarine and river sampling. Thirty locations were visited; 3 river sampling sites, 1 estuarine site, and 26 in the coastal ocean (Fig. 1). Our data set included a quasi-monthly sampling at the Coastal Time Series Station of the COPAS Center (Station 18, http://www.copas.udec. $\mathrm{cl} / \mathrm{eng} / \mathrm{research} / \mathrm{serie})$. This coastal station is characterized by a marked seasonality in hydrographic conditions as a result of intensive upwelling during austral spring and summer, and the freshwater input during winter (Sobarzo et al., 2007). Seasonality is also observed in marine productivity and community respiration (Montero et al., 2007), chlorophyll- $a$ and phytoplankton biomass (González et al., 2007).

Seawater and river samples were collected with Niskin bottles and polypropylene carboys for surface samples, which were used for the determination of nutrients, chlorophyll- $a$, proteins, primary production and extracellular hydrolysis of proteins and carbohydrates. Water samples for these parameters were collected at several depths between 1 and $110 \mathrm{~m}$. Surface $(0-1$ and $1-2 \mathrm{~cm})$ sediment samples were collected with a box corer or a Van Veen grab, then stored at $4{ }^{\circ} \mathrm{C}$ until arrival at the laboratory to be processed for hydrolysis incubation experiments.

\subsection{Water column measurements}

Temperature, salinity and oxygen in the water column were recorded with a Sea Bird SBE 19 plus CTD and data were processed with the Ocean Data View 4.3.5 software (Schlitzer, 2010). Water samples for $\mathrm{NO}_{3}^{-}$were filtered through $0.7 \mu \mathrm{m}$ (Whatman GFF) and both filtrate and filters were frozen at $-20^{\circ} \mathrm{C}$. The filtrate was analyzed for nitrate with the spectrophotometric method of Strickland and Parsons (1972), and filters were split for the determination of chlorophyll- $a$ by fluorometry (Parsons et al., 1984) and particulate proteins by HPLC. Particulate proteins were analyzed as total hydrolyzable amino acids by high pressure liquid chromatography coupled to an on-line fluorescence detector set up at $330 \mathrm{~nm}$ (excitation) and $450 \mathrm{~nm}$ (emission) on a Shimadzu HPLC, fluorescence detector, and autosampler. Subsamples of filters were placed in $2 \mathrm{~mL}$ of $\mathrm{N}_{2}$-purged hydrolysis solution for $1.5 \mathrm{~h}$ at $150{ }^{\circ} \mathrm{C}$ and neutralized. Aliquots of the neutralized solution were derivatized before injection with o-phthaldialdehyde and 2-mercaptoethanol according to Mopper and Lindroth (1982). Separation and quantification of 15 amino acids were done in a C18 Kromasil column using a gradient program of $0.025 \mathrm{M}$ sodium acetate and $5 \%$ tetrahydrofurane. Dissolved proteins were analyzed as dissolved combined amino acids on subsamples of acidified filtered seawater after subtracting the concentration of dissolved free amino acids. HPLC analysis was performed as before.

Determinations of rates of primary production were carried out at 5, 10, 20, 30 and $40 \mathrm{~m}$ depth at Station 14 (Fig. 1) from changes in dissolved oxygen concentrations observed after incubating in situ light and dark bottles (Strickland, 1960). Water from Niskin bottles was transferred to $125 \mathrm{~mL}$ borosilicate bottles (gravimetrically calibrated). At each incubation depth, five clear and five darkened bottles were incubated in situ for 8-9 h, attached to a surface buoy mooring anchored to the ocean floor, and then treated with the Winkler reagents. Oxygen concentrations were determined manually according to the Winkler method (Strickland and Parsons, 1972) using an automatic Dosimat Metrohm 665 burette and by visual end-point detection. Oxygen production was converted to carbon units using a photosynthetic quotient of 1.25 and rates calculated as $\left[\mathrm{O}_{2}\right]$ after incubation in clear bottles minus $\left[\mathrm{O}_{2}\right]$ after incubation in darkened bottles. Discrete primary production rates were integrated for the whole water column. Our data were combined with additional primary production measurements published by Daneri et al. (2000) in the area $35^{\circ} 00^{\prime} \mathrm{S}$ to $39^{\circ} 00^{\prime} \mathrm{S}$ and $73^{\circ} 00^{\prime} \mathrm{W}$ to $75^{\circ} 00^{\prime}$ from 36 observations from 1989 to 1991.

One-liter water subsamples from Niskin bottles were immediately removed and placed in acid-clean carboys until arrival in the laboratory ( $10 \mathrm{~h}$ later). Carboys with water samples were darkened and kept at $4-7^{\circ} \mathrm{C}$ on board using water baths with icepacks or a refrigerator. While the incubation system was being prepared back in the laboratory (1-2h), carboys were kept in a cold chamber at $4-7^{\circ} \mathrm{C}$ in the darkness. After addition of the substrate, flasks were incubated at ca. $10^{\circ} \mathrm{C}$ under continuous agitation. This temperature is representative of the in situ temperature $\left(9.9-12.8^{\circ} \mathrm{C}\right)$.

Estimates of extracellular enzymatic activity were conducted based on duplicate $5 \mathrm{~mL}$-aliquots of seawater, which were incubated in darkness with Lleucine-4-methylcoumarinyl-7-amide (MCA-leu), 4methylumbelliferyl-ß-D-cellobiose (MUF-cel) and 4methylumbelliferyl-B-D-glucoside (MUF-glu) at $10 \mu \mathrm{M}$ final concentrations (Hoppe, 1983). Fluorescence was measured at time zero, and every $2 \mathrm{~h}$ for $6 \mathrm{~h}$ at $365 \mathrm{~nm}$ excitation 
Table 1. Sampling cruises and samples collected from 2006 to 2010 in the study area.

\begin{tabular}{|c|c|c|}
\hline Area/Cruise & Mo/yr & Measurements \\
\hline Coastal zone (PIMEX 1) & $08 / 2006$ & $\begin{array}{l}\mathrm{O}_{2} \text {, temperature, salinity, nutrients, chlorophyll- } a \text {, sediment stable isotopes, } \\
\text { primary production rates }\end{array}$ \\
\hline Coastal zone (PIMEX 2) & $01 / 2007$ & $\begin{array}{l}\mathrm{O}_{2} \text {, temperature, salinity, nutrients, chlorophyll- } a \text {, sediment stable isotopes, } \\
\text { primary production rates, carbon sinking fluxes, particulate protein, } \\
\text { enzymatic hydrolysis }\end{array}$ \\
\hline Coastal zone (PIMEX 3) & 08/2007 & $\begin{array}{l}\mathrm{O}_{2} \text {, temperature, salinity, nutrients, chlorophyll- } a \text {, sediment stable isotopes, } \\
\text { carbon sinking fluxes, particulate protein, } \\
\text { enzymatic hydrolysis }\end{array}$ \\
\hline River \& Estuary & $10 / 2007$ & $\mathrm{O}_{2}$, temperature, salinity, nutrients, chlorophyll- $a$, enzymatic hydrolysis \\
\hline River \& Estuary & $01 / 2008$ & Enzymatic hydrolysis \\
\hline Coastal zone (PIMEX 4) & $04 / 2008$ & Primary production rates, carbon sinking fluxes, enzymatic hydrolysis \\
\hline Coastal zone (PIMEX 5) & $06 / 2009$ & $\mathrm{O}_{2}$, temperature, salinity, nutrients, chlorophyll- $a$, enzymatic hydrolysis \\
\hline Coastal zone (PIMEX 6) & $07 / 2009$ & $\mathrm{O}_{2}$, temperature, salinity, nutrients, chlorophyll- $a$, enzymatic hydrolysis \\
\hline Coastal zone (PIMEX 7) & $10 / 2009$ & $\mathrm{O}_{2}$, temperature, salinity, nutrients, chlorophyll- $a$, enzymatic hydrolysis \\
\hline Coastal zone (PIMEX 8) & $01 / 2010$ & $\mathrm{O}_{2}$, temperature, salinity, nutrients, chlorophyll- $a$, enzymatic hydrolysis \\
\hline Coastal zone (PIMEX 9) & $08 / 2010$ & $\mathrm{O}_{2}$, temperature, salinity, nutrients, chlorophyll- $a$, enzymatic hydrolysis \\
\hline River \& Estuary & $08 / 2010$ & $\mathrm{O}_{2}$, temperature, salinity, nutrients, chlorophyll- $a$, enzymatic hydrolysis \\
\hline Coastal zone (PIMEX 10) & $10 / 2010$ & $\mathrm{O}_{2}$, temperature, salinity, nutrients, chlorophyll- $a$, enzymatic hydrolysis \\
\hline Coastal zone & $01,02,03,05,09,10 / 2008 \&$ & $\mathrm{O}_{2}$, temperature, salinity, nutrients, chlorophyll- $a$, enzymatic hydrolysis \\
\hline (St. 18 COPAS Time Series) & $01,02,03,04,05,08,09,11 / 2009$ & \\
\hline
\end{tabular}

and $455 \mathrm{~nm}$ emission. Boiled seawater was used to check background fluorescence, which was negligible at those wavelengths.

Calibration curves were constructed by measuring the fluorescence of standard solutions of MCA and MUF prepared in unfiltered seawater at concentrations ranging between 0.03 and $0.5 \mu \mathrm{M}$. Standard curves were prepared for each experiment. A one-point calibration was done at the beginning of the incubation using $0.5 \mu \mathrm{M} \mathrm{MCA}$ and the calibration curve at the end of every experiment with hydrolysis products MCA and MUF at concentrations ranging between 0.03 and $0.5 \mu \mathrm{M}$. The largest change in fluorescence before and after the experiment for the $0.5 \mu \mathrm{M}$ MCA was $2 \%$. First order rate constants were calculated from the slope of the plot $\ln \left[\mathrm{C}_{0} /\left(\mathrm{C}_{0}-\mathrm{P}\right)\right]$ vs. time, where $\mathrm{C}_{0}$ is the initial concentration of the substrate (MCA-leu, MUF-glu, MUF-cel) and $\mathrm{P}$ is the concentration of the product (MCA, MUF) at time $t$ (Pantoja and Lee, 1994). Actual hydrolysis rates were calculated by multiplying rate constants by $\mathrm{C}_{0}$. Discrete rates were depth-integrated throughout the water column, and carbon hydrolysis rates calculated using the conversion factor of 72 for MUF-glu and MCA-leu, and 144 for MUF-cel (Hoppe, 1983).

During April 2007, we determined the enzyme parameters $K_{\mathrm{S}}$ and $V_{\max }$ with MCA-leu and MUF-cel by incubating surface water samples using 0.75, 5, 20, 50, 100, 250, and $500 \mu \mathrm{M}$ of substrates. All experimental samples were treated as described above.

\subsection{Surface sediment measurements}

Sediment samples were maintained in containers with icepacks or in a refrigerator at $4{ }^{\circ} \mathrm{C}$ until arrival in the laboratory (within $10 \mathrm{~h}$ ). Estimates of extracellular enzymatic activity in sediments were carried out in duplicate undisturbed sediment mini-cores containing $\sim 10 \mathrm{~mL}$ wet sediment. Sediments were inoculated with MCA-leu, MUF-cel, and MUFglu at $\sim 50 \mu \mathrm{M}$ final concentrations (Meyer-Riel, 1986), and incubated in the dark at ca. $10^{\circ} \mathrm{C}$. At time courses 0 and $9 \mathrm{~h}$, the sediment was centrifuged at $3500 \mathrm{rpm}$ for $5 \mathrm{~min}$, and the supernatant was filtered through $0.2 \mu \mathrm{m}$ Durapore filters and the fluorescence measured. Calibration curves were determined with pore water as described above. Boiled sediment was used to check background fluorescence, which was negligible at those wavelengths. Grams of dry sediment were transformed to sediment volume as in Berner (1980).

Primary production rates, hydrolysis rates of the water column and the hydrolysis rates in surface sediments were averaged for winter (June to August), and the period springsummer (September to March).

\section{Results}

\subsection{Physical-chemical and biological characteristics in the coastal area adjacent to the Itata river mouth}

Seasonal variability was observed in the vertical distribution of temperature. Thus, during winter cold waters $\left(<11-12^{\circ} \mathrm{C}\right)$ were homogeneously distributed in the water column (Fig. 2a). In contrast, during spring and summer 


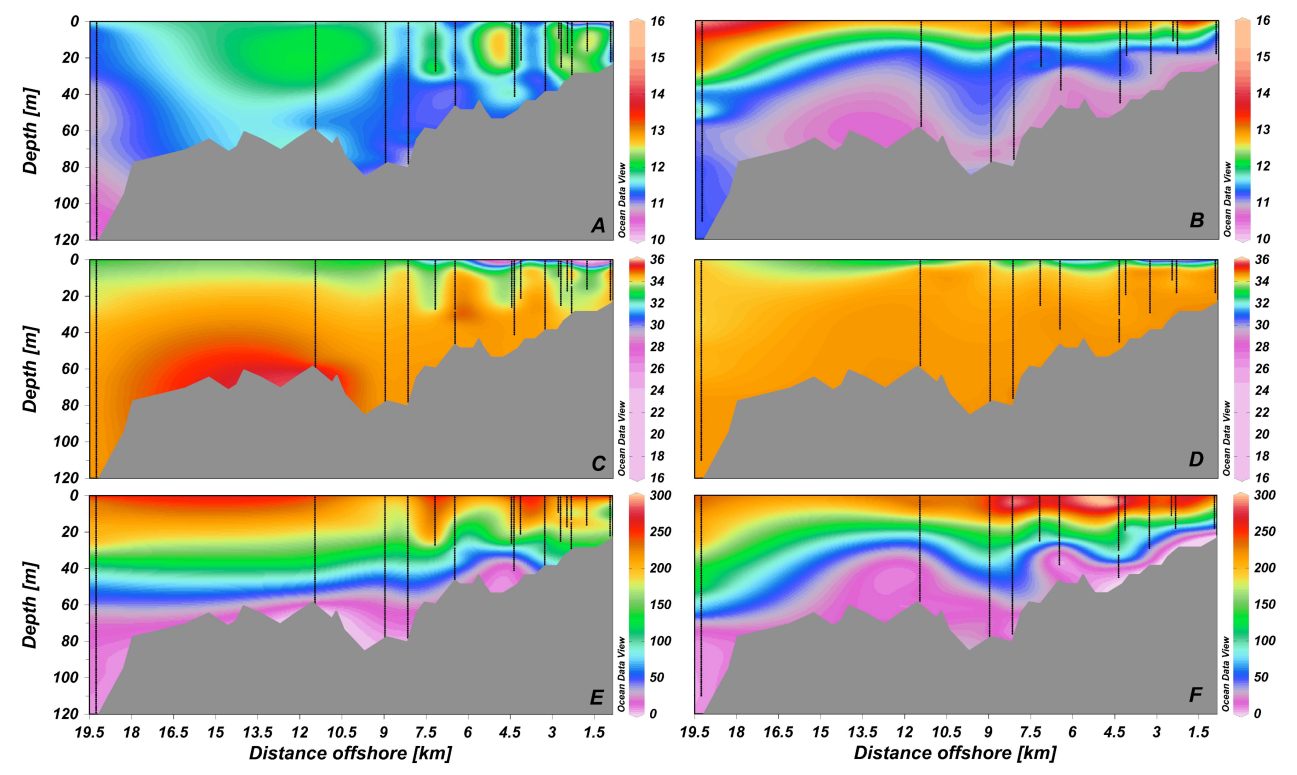

Fig. 2. Cross sections of temperature $\left({ }^{\circ} \mathrm{C}\right.$, panels $\left.\mathbf{A}, \mathbf{B}\right)$, salinity (panels $\left.\mathbf{C}, \mathbf{D}\right)$, oxygen $(\mu \mathrm{M}$, panels $\mathbf{E}$, F) during austral winter (left) and spring-summer (right) panels in the Itata river and the adjacent coastal area. X-axis is the distance from the coast. Map generated using the software Ocean Data View (Schlitzer, 2010).

temperatures higher than $13^{\circ} \mathrm{C}$ and a stratified water column were observed (Fig. 2b). The horizontal distribution of temperature showed changes seaward, with the thermocline observed at $\sim 10 \mathrm{~m}$ at coastal stations and $\sim 30 \mathrm{~m}$ at offshore stations during the spring-summer period (Fig. 2b). In contrast, during winter temperature remained homogeneously distributed along the gradient (Fig. 2a).

Seasonal variability in salinity was also observed in surface waters, with low salinity (28.5-33) recorded during winter in the top $\sim 5 \mathrm{~m}$ depth, indicating the influence of freshwater from the Itata river discharge reaching more than $7 \mathrm{~km}$ offshore (Fig. 2c). During spring and summer, salinity was more homogeneously distributed and the influence of freshwater was restricted to surface waters in the top $\sim 3 \mathrm{~km}$ offshore (Fig. 2d).

Permanently suboxic conditions $\left(<22 \mu \mathrm{M} \mathrm{O}_{2}\right)$ were evidenced below $\sim 60 \mathrm{~m}$ depth during the entire sampling period (Fig. 2e and f). Although no major temporal changes were observed in oxygen concentrations, during spring-summer the oxycline raised about $20 \mathrm{~m}$ in coastal stations (Fig. 2f). That pattern was similar to those observed for temperature (with cold waters reaching about $20 \mathrm{~m}$ ) indicative of upwelling waters.

The concentration of nitrate ranged between 5 and $20 \mu \mathrm{M}$ in the top $\sim 30 \mathrm{~m}$ during winter (Fig. 3a). Below this depth, concentration of nitrate was in the order of $25 \mu \mathrm{M}$ (Fig. 3a). Nitrate ranged between 10 and $20 \mu \mathrm{M}$ in the top $20 \mathrm{~m}$ during spring-summer (Fig. 3b). The highest concentrations $(\sim 40 \mu \mathrm{M})$ of nitrate during the austral spring and summer were observed in bottom waters (Fig. 3b), reaching ca. $20 \mathrm{~m}$ depth toward coastal stations, suggesting the effect of seasonal upwelling as described before.

Suspended particulate chlorophyll- $a$ showed large differences between the austral winter and spring-summer (Fig. 3c and d). During the latter, values in the range of 10 and $>30 \mathrm{mg} \mathrm{m}^{-3}$ were observed in surface waters (Fig. 3d), while during winter, maximum chlorophyll- $a$ only reached values of about $5 \mathrm{mg} \mathrm{m}^{-3}$ (Fig. 3c). Along the seaward gradient, the highest concentrations of chlorophyll- $a$ were observed within $15 \mathrm{~km}$ from the coast in surface waters during spring-summer (Fig. 3d).

Suspended particulate proteins in the water column showed differences in surface waters depending on season, $>2 \mu \mathrm{M}$ during spring-summer in the upper $20 \mathrm{~m}$, and about $1 \mu \mathrm{M}$ during winter (Fig. 4). Below $30 \mathrm{~m}$ depth, concentrations decreased to ca. $0.5 \mu \mathrm{M}$ in both winter (Fig. 4a) and spring-summer (Fig. 4b). Concentration of dissolved proteins (as dissolved combined amino acids) was generally higher in winter than in spring-summer and generally increasing with depth in winter (Fig. $4 \mathrm{c}$ and d). Spring-summer concentrations decreased with depth from a maximum of $3.1 \mu \mathrm{M}$ at $10 \mathrm{~m}$ depth to a minimum of $1.2 \mu \mathrm{M}$ below $40 \mathrm{~m}$ (Fig. 4d).

\subsection{Extracellular enzymatic hydrolysis in the water column from the river to $20 \mathrm{~km}$ offshore}

Extracellular enzymatic hydrolysis in surface seawater was dominated by aminopeptidase activity (MCA-leu), which ranged from 1.2 to $182 \mathrm{nmoll}^{-1} \mathrm{~h}^{-1}$ and was at least one 


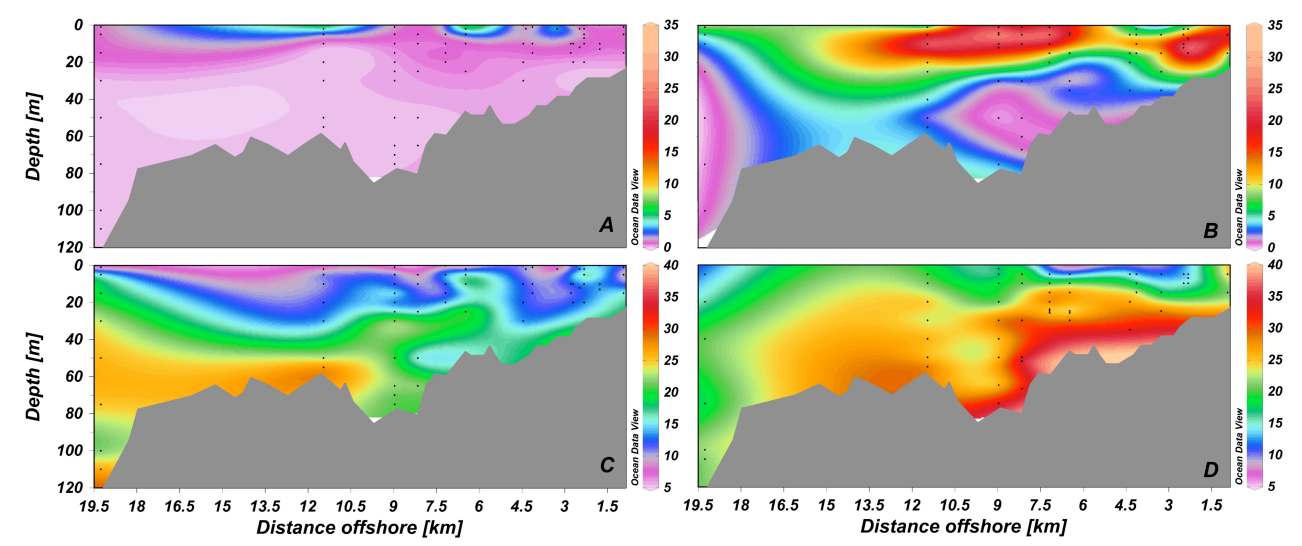

Fig. 3. Cross sections of nitrate $(\mu \mathrm{M}$, panels $\mathbf{A}, \mathbf{B})$, chlorophyll- $a\left(\mathrm{mg} \mathrm{m}^{-3}\right.$, panels $\left.\mathbf{C}, \mathbf{D}\right)$ during austral winter (left) and spring-summer (right) panels in the Itata river and the adjacent coastal area. X-axis is the distance from the coast. Map generated using the software Ocean Data View (Schlitzer, 2010).

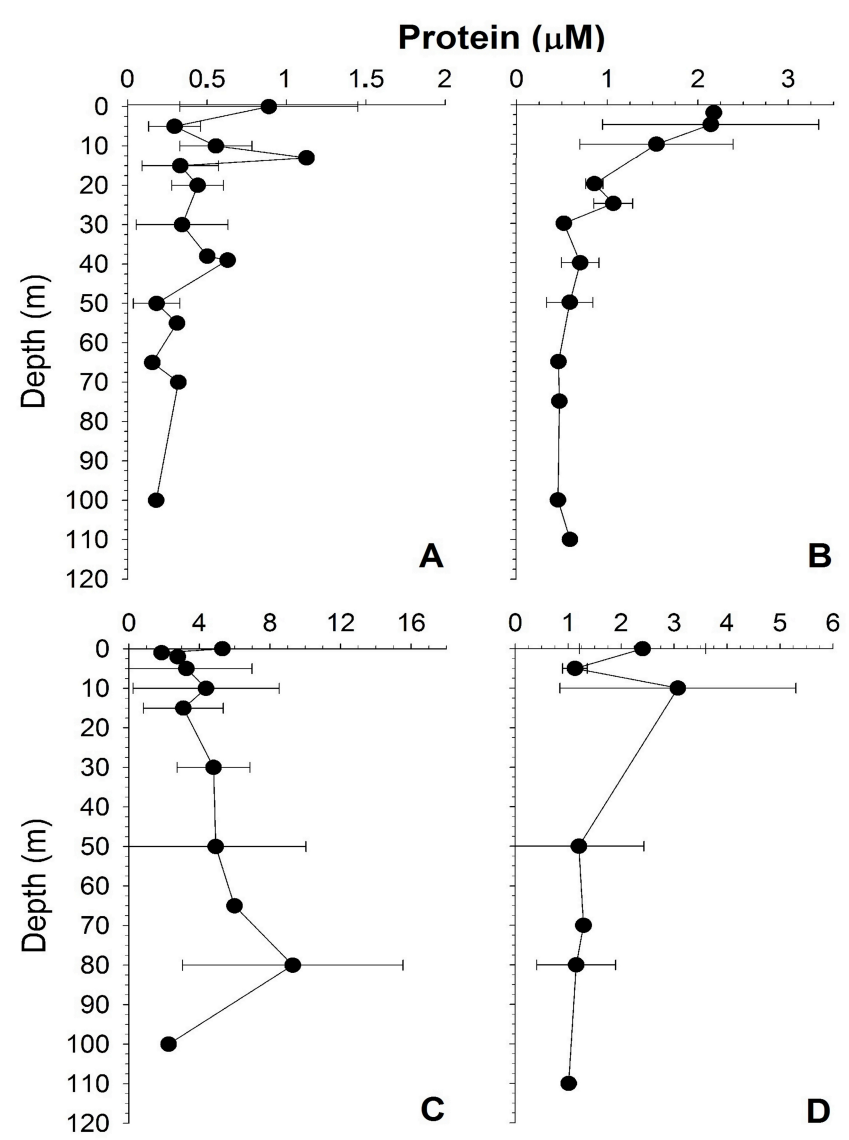

Fig. 4. Suspended particulate $(\mathbf{A}, \mathbf{B})$ and dissolved $(\mathbf{C}, \mathbf{D})$ protein concentration in the water column $(\mu \mathrm{M})$ during the austral winter (left panels) and spring-summer (right panels). Values are average determinations for all sampling sites and depth. Bars are standard deviations. order of magnitude higher than the activity observed for substrates MUF-glu (0.08-61 nmol $\left.\mathrm{l}^{-1} \mathrm{~h}^{-1}\right)$ and MUF-cel $\left(0.15-7 \mathrm{nmol}^{-1} \mathrm{~h}^{-1}\right)$ (Fig. 5). Seasonal differences were observed in extracellular enzymatic activity with the highest hydrolysis rates of MCA-leu (181.9 $\left.\mathrm{nmol}^{-1} \mathrm{~h}^{-1}\right)$, MUFglu $\left(61 \mathrm{nmoll}^{-1} \mathrm{~h}^{-1}\right)$, and MUF-cel $\left(7 \mathrm{nmol}^{-1} \mathrm{~h}^{-1}\right)$ during spring- summer in the coastal area between 0 and $20 \mathrm{~km}$ from the coast (Fig. 5b, d, f). During winter, extracellular hydrolysis in the coastal area decreased to values ranging from 1.2 to $56.7 \mathrm{nmoll}^{-1} \mathrm{~h}^{-1}$ for MCA-leu and from 0.08 to $6.9 \mathrm{nmol}^{-1} \mathrm{~h}^{-1}$ for glucosidic substrates MUF-cel and MUF-glu (Fig. 5a, c, e).

Along the river stations, extracellular enzymatic hydrolysis remained within the range of 40 to $131 \mathrm{nmoll}^{-1} \mathrm{~h}^{-1}$ for MCA-leu and about $20 \mathrm{nmoll}^{-1} \mathrm{~h}^{-1}$ for glucosidic substrates during winter (Fig. 5a, c, e). During summer, hydrolysis of MCA-leu averaged $101 \pm 20 \mathrm{nmoll}^{-1} \mathrm{~h}^{-1}$ in the river, $83.3 \pm 20 \mathrm{nmoll}^{-1} \mathrm{~h}^{-1}$ in the estuary and $93.5 \pm 50.2 \mathrm{nmoll}^{-1} \mathrm{~h}^{-1}$ in coastal waters. During springsummer extracellular hydrolysis of MCA-leu in riverine waters averaged $96 \pm 20 \mathrm{nmol}^{-1} \mathrm{~h}^{-1}(n=7)$ and was similar to those observed in coastal waters $93.5 \pm 50.2 \mathrm{nmoll}^{-1} \mathrm{~h}^{-1}$ ) $(n=34)$. No major changes in hydrolysis rates were observed between riverine and coastal waters for MUF-glu (Fig. 5c, d), while MUF-cel hydrolysis was higher in the river than in coastal waters (Fig. 5e, f). The ratio of the potential activity of protein vs. carbohydrate hydrolysis $\left[\left(k_{\mathrm{MCA}-\text { leu }}\right) /\left(k_{\mathrm{MUF}-\mathrm{cel}}+k_{\mathrm{MUF}-\mathrm{glu}}\right)\right]$ showed a general increase towards the marine sites (Fig. 6a), which was more pronounced during winter (inset Fig. 6a). 

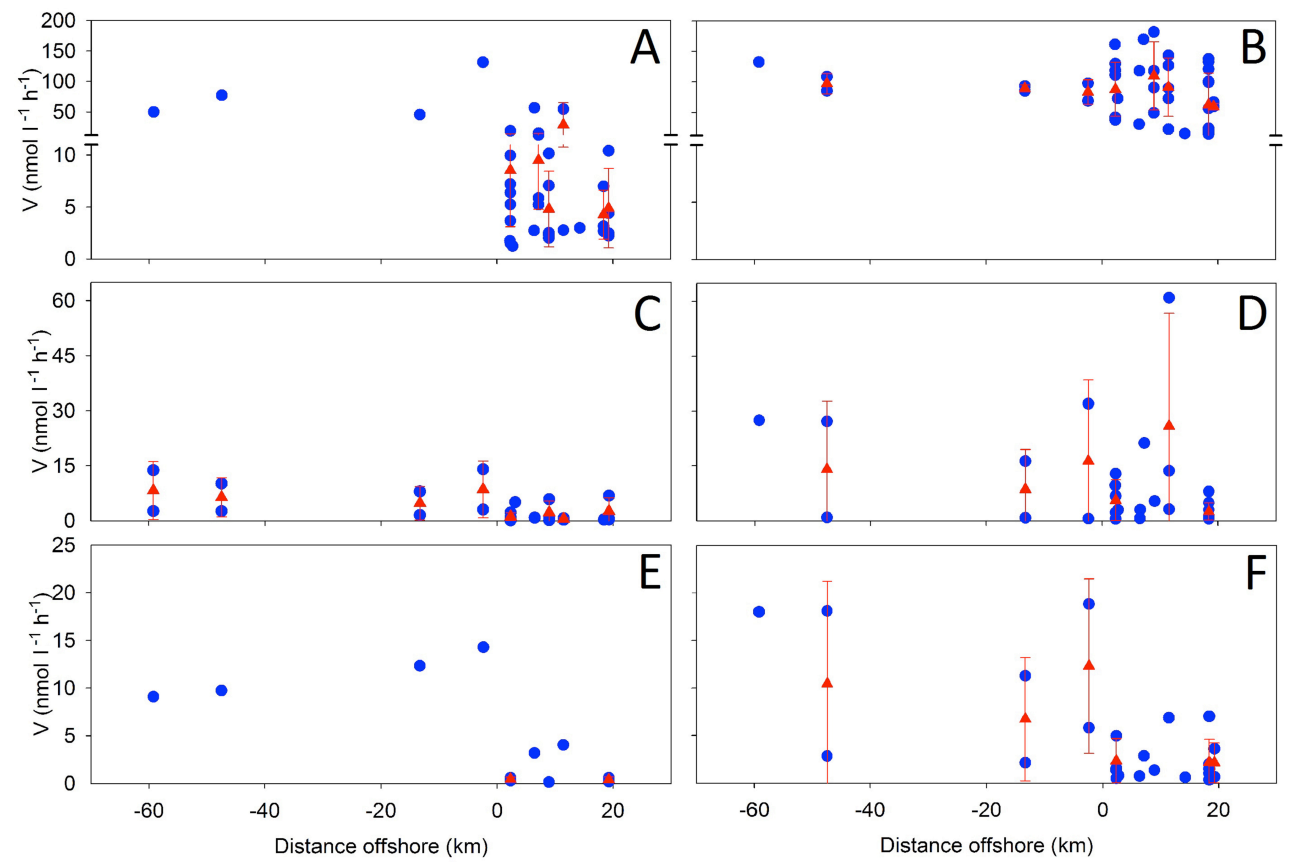

Fig. 5. Enzymatic extracellular hydrolysis of substrates MCA-leu (A, B), MUF-glu (C, D), MUF-cel (E, F) in surface waters during the winter (left panels) and spring-summer (right panels) in relation to distance from the coast (negative distances represent river sampling sites). Rates are in nmol $1^{-1} \mathrm{~h}^{-1}$. Blue symbols are discrete values and red symbols are average rates $( \pm \mathrm{SD})$ if possible.

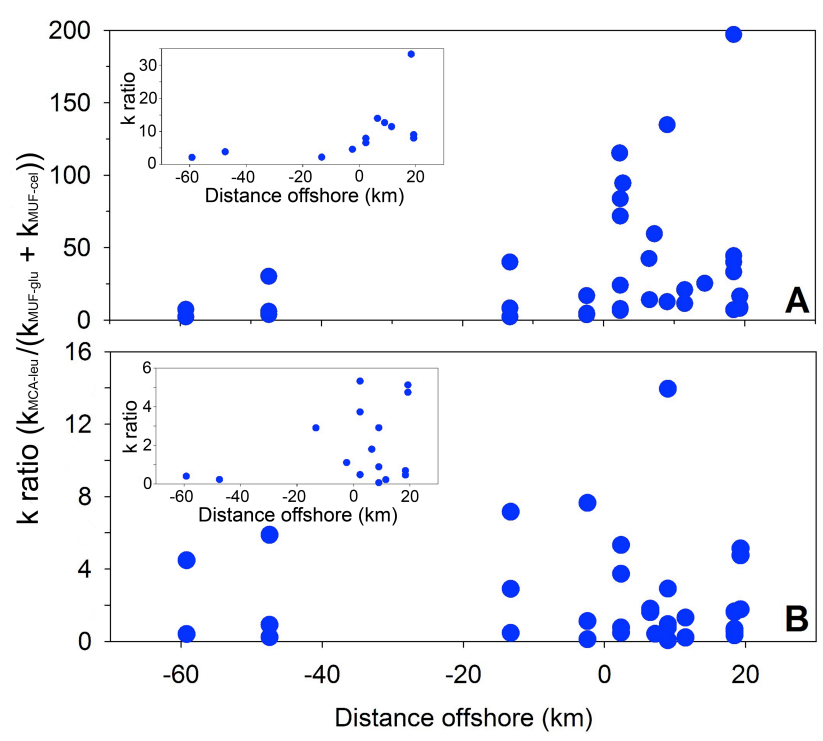

Fig. 6. Relationship between the ratio of hydrolysis rate constants (k) $k_{\mathrm{MCA}-\mathrm{leu}} /\left(k_{\mathrm{MUF}-\mathrm{glu}}+k_{\mathrm{MUF}-\mathrm{cel}}\right)$ and distance from the coast (negative distances represent river sampling sites) for the water column (A) and surface sediments (B). The insets show the winter data.

\subsection{Extracellular enzymatic hydrolysis in surface sediments along a river-offshore gradient}

Contrary to the observed for the water column, in surface sediments extracellular enzymatic hydrolysis of MCAleu ( 0.04 to $\left.6.13 \mathrm{nmolg}^{-1} \mathrm{dwh}^{-1}\right)$ was in the same order of magnitude to those observed for MUF-cel (0.004 to $5.1 \mathrm{nmol} \mathrm{g}^{-1} \mathrm{dwh}^{-1}$ ) and MUF-glu (0.007 to $10.5 \mathrm{nmol} \mathrm{g}^{-1} \mathrm{dw} \mathrm{h}^{-1}$ ) substrates (Fig. 7). In addition, seasonality of hydrolysis was characterized by higher rates during winter than in spring-summer in the coastal and estuarine zones (Fig. 7). Extracellular hydrolysis of MCAleu ranged from 0.04 to $6.13 \mathrm{nmol} \mathrm{g}^{-1} \mathrm{dw} \mathrm{h}^{-1}$ during winter (Fig. 7a), and from 0.24 to $2.78 \mathrm{nmol} \mathrm{g}^{-1} \mathrm{dw} \mathrm{h}^{-1}$ during spring-summer (Fig. 7b). For glucosidic substrates, extracellular hydrolysis during winter ranged between 0.007 and $13.1 \mathrm{nmol} \mathrm{g}^{-1} \mathrm{dw} \mathrm{h}^{-1}$ (Fig. 7c, e) and during spring and summer from 0.27 to $9.33 \mathrm{nmol} \mathrm{g}^{-1} \mathrm{dw} \mathrm{h}^{-1}$ (Fig. $7 \mathrm{~d}, \mathrm{f}$ ) in the area adjacent to the Itata river discharge.

No major seasonal changes were observed in extracellular enzymatic hydrolysis in riverine sediments, and the estimated rates were in the low range of those observed for coastal sediments (Fig. 7). Hydrolysis of MCA-leu ranged from 0.07 to $2.3 \mathrm{nmol} \mathrm{g}^{-1} \mathrm{dw} \mathrm{h}^{-1}$ during winter and from 0.11 to $0.38 \mathrm{nmol} \mathrm{g}^{-1} \mathrm{dw} \mathrm{h}^{-1}$ during spring-summer (Fig. 7a and b). For glucosidic substrates, hydrolysis rates ranged from $0.30-0.86$ and $0.069-1.7 \mathrm{nmol} \mathrm{g}^{-1} \mathrm{dw} \mathrm{h}^{-1}$ during spring-summer (Fig. $7 \mathrm{~d}$ and $\mathrm{f}$ ) and winter (Fig. $7 \mathrm{c}$ 


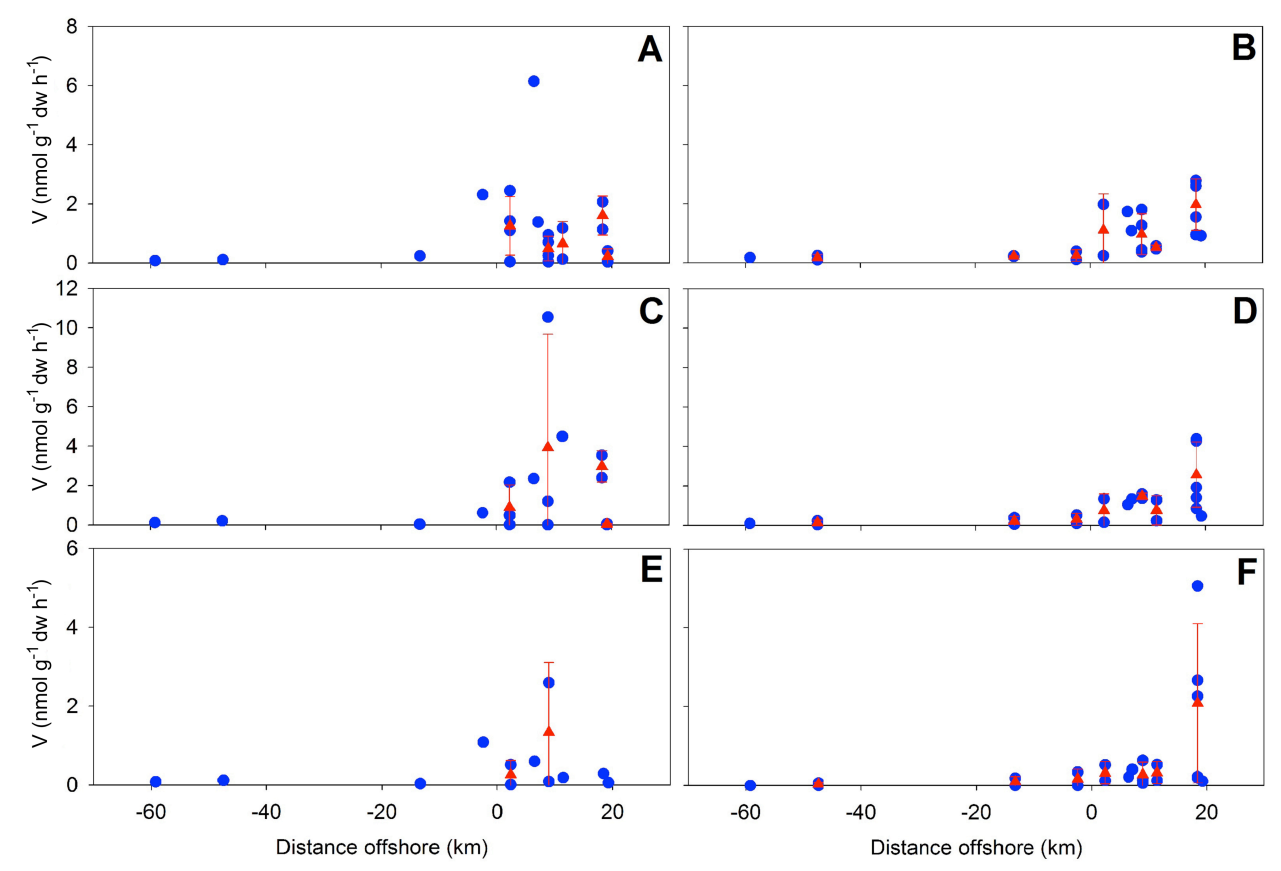

Fig. 7. Enzymatic extracellular hydrolysis of substrates MCA-leu (A, B), MUF-glu (C, D), MUF-cel (E, F) in surface sediment during winter (left panels) and spring-summer (right panels) in relation to distance from the coast (negative distances represent river sampling sites). Rates are in $n m o l 1^{-1} h^{-1}$. Blue symbols are discrete values and red symbols are average rates $( \pm \mathrm{SD})$ when possible.

and e). The ratio of protein to carbohydrate hydrolysis $\left[\left(k_{\mathrm{MCA}-\mathrm{leu}} /\left(k_{\mathrm{MUF}-\mathrm{cel}}+k_{\mathrm{MUF}-\mathrm{glu}}\right)\right]\right.$ remained approximately constant throughout the year and across the river and shelf surface sediments (Fig. 6b). In almost $50 \%$ of the cases carbohydrate hydrolysis was higher than MCA-leu rates (inset Fig. 6b).

The comparison of rates of hydrolysis of MCA-leu over time at a site near the outfall pipe did not show any difference in degradation attributable to the effect of the discharge from the secondary treatment of the pulp mill industry in the water column (Fig. 8a). On surface sediments, we observed an increase in extracellular enzymatic activity in the few measurements carried out after the outflow was introduced in this coastal area (Fig. 8b). Considering that the outfall pipe ( $30 \mathrm{~m}$ depth) remains below the thermocline when the water column is stratified (spring and summer), we cannot rule out any possible effect of the outflow on surface sediments.

\section{Discussion}

\subsection{Physical-chemical and biological characteristics in the coastal area adjacent to the Itata river mouth}

Temporal changes in hydrographic conditions were observed in the coastal area adjacent to the Itata river reflecting the seasonal variability described for the Humboldt Current System off central-southern Chile (Strub et al., 1998; Daneri et
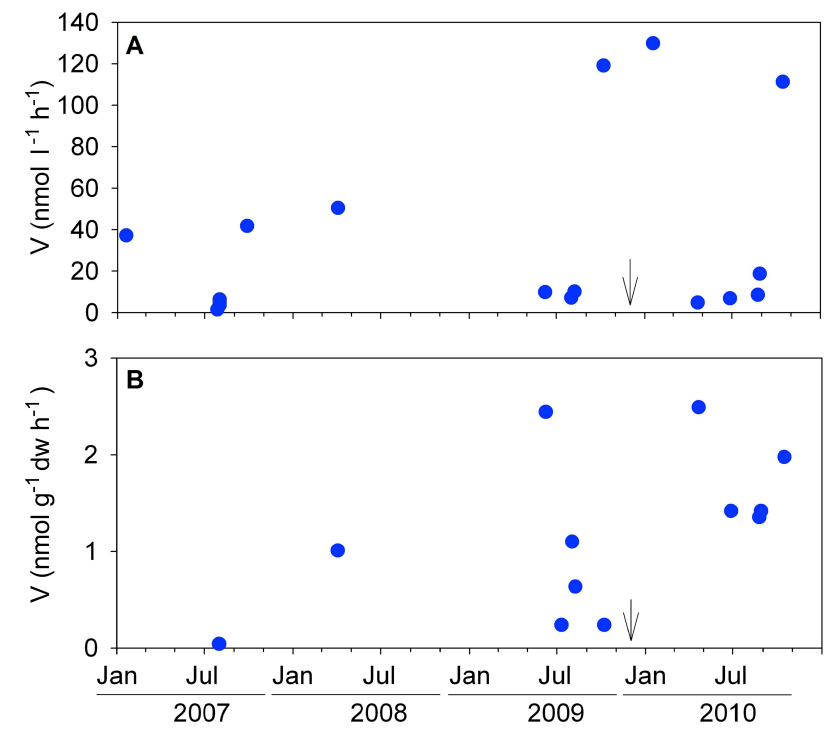

Fig. 8. Hydrolysis rates of MCA-leu in surface water (panel A) and surface sediment (panel B) at sampling station 6 (Fig. 1), where a sewage outfall was installed on December 2009 (vertical arrow).

al., 2000; Figueroa and Moffat, 2000; Sobarzo et al., 2007). During spring-summer, an increase in surface temperature and a shallow thermocline indicates a stratified water column (Fig. 2a and b). During this period, cold, nutrient-rich and 
Table 2. Primary production in the upper $40 \mathrm{~m}$ of the water column in central-southern Chile according to Daneri et al. (2000), and measurements carried out during this study in January 2007, April 2008, and August 2006.

\begin{tabular}{lc}
\hline Month/year & $\begin{array}{c}\text { Primary production } \\
\left(\mathrm{mol} \mathrm{C} \mathrm{m}^{-2} \mathrm{~d}^{-1}\right)\end{array}$ \\
\hline January & 0.48 \\
January-07 & 0.10 \\
February & 0.08 \\
March & 0.19 \\
April & 0.16 \\
April-08 & 0.06 \\
May & 0.15 \\
June & 0.08 \\
July & 0.04 \\
August & 0.05 \\
August-06 & 0.00 \\
September & 0.41 \\
October & 0.25 \\
November & 0.51 \\
December & 0.17 \\
\hline
\end{tabular}

oxygen-depleted waters reaches ca. $20 \mathrm{~m}$ depth in the coastal area (Fig. 2), pointing to the influence of upwelling conditions on the vertical structure of the water column. During winter, a low salinity layer along the coastal offshore gradient in surface waters $(\sim 0-5 \mathrm{~m})$ was observed (Fig. $2 \mathrm{c}$ and d), indicating the influence of the freshwater input from the Itata river. These seasonal changes in hydrographic variability are consistent with previous studies in this coastal ecosystem (Sobarzo et al., 2007) that identified both upwelling events and freshwater influx from the river discharges as the main processes determining the vertical structure of the water column.

As a consequence of the upwelling, high primary production is observed in the coastal ecosystem off centralsouthern Chile during spring and summer (Daneri et al., 2000; Montero et al., 2007). Our results for the area adjacent of the Itata river mouth showed differences in productivity rates between austral winter $\left(\sim 0 \mathrm{~mol} \mathrm{C} \mathrm{m}^{-2} \mathrm{~d}^{-1}\right)$ and spring- summer $\left(0.1 \mathrm{~mol} \mathrm{C} \mathrm{m}^{-2} \mathrm{~d}^{-1}\right)$. These values were in the range of previous measurements in the area (Table 2) (Daneri et al. (2000). In addition, higher values of primary production during summer were accompanied by high concentrations of chlorophyll- $a$ (Fig. 3b) and particulate proteins (Fig. 4b). During winter, photosynthetic production in the coastal ecosystem off Chile decreases (Daneri et al., 2000; Montero et al., 2007), as reflected by chlorophyll- $a$ (Fig. 3a) and proteins (Fig. 4a) observed in the study area.

\subsection{Extracellular enzymatic hydrolysis in seawater and surface sediments}

The saturation experiment resulted in a $K_{\mathrm{s}}$ (MichaelisMenten constant) and $V_{\max }$ of $12 \mu \mathrm{moll}^{-1}$ and $0.13 \mu \mathrm{mol}^{-1} \mathrm{~h}^{-1}$, respectively, for MCA-leu and of $38 \mu \mathrm{M}$ and $1 \mu \mathrm{mol} \mathrm{l}^{-1} \mathrm{~h}^{-1}$ for MUF-cel. For comparison of $\mathrm{K}_{\mathrm{s}}$ the concentration of dissolved proteins in surface waters averages $3.8 \pm 2.6 \mu \mathrm{M}$ in winter and $2.5 \pm 2.7 \mu \mathrm{M}$ in spring summer of the study area (Fig. 4c and d), and polysaccharide concentrations range from 1 to $82 \mu \mathrm{M}$ for several oceans (Pakulski and Benner, 1994; Myklestad and Børsheim, 2007).

Several patterns in the rates of hydrolysis are observed in this study. First of all, rates of hydrolysis of protein substrates were 4 to 7 times higher than those of carbohydrates in seawater (Fig. 5). This pattern has been previously observed (e.g. Arnosti, 2011) and has been attributed to the preferential mineralization of organic nitrogen with respect to carbon in the marine environment (Lee et al., 2004), and may be supported by more bacterial taxa with genes encoding transporters of amino acids rather than sugars (Poretsky et al., 2009). In estuarine and riverine waters and sediments, we observed that rates of hydrolysis of protein were 5-10 times faster than hydrolysis of carbohydrates (Fig. 5). Within the water column, hydrolysis rates of all substrates were always higher in surface waters (data not shown), as previously shown for this ecosystem (Gutiérrez et al., 2011) and other coastal areas such as the Gulf of Genoa, off the Ligurian Coast in the Mediterranean Sea (Misic and Fabiano, 2006), as well as in the upwelling ecosystem of northern Chile (Pantoja et al., 2009). This pattern is attributed to the enhancement of primary production and associated exudation of organics in the photic zone (Gutiérrez et al., 2011), a trend that has also been observed with amino peptidase activity along an eutrophication gradient in lakes (Chróst and Siuda, 2006). A correlation analysis using Spearman rank order resulted in significant association of water column hydrolysis of all substrates with chlorophyll- $a,(p<0.006)$, and of MCA-leu with chlorophyll- $a$, temperature and oxygen $(p<0.0003)$. These results coincide with the general idea of enhancement of hydrolytic activity with substrate availability previously stated.

We observed seasonal differences in the potential activity on glucosidic and protein substrates in river, estuarine and coastal waters (Fig. 5). Hydrolysis of the three substrates was higher during winter in the river and the estuary compared to marine sites, whereas in spring-summer, this pattern was not evident and hydrolysis of MCA-leu and MUF-glu was approximately constant across all environments, showing a decrease in activity of MUF-cel towards marine sites (Fig. 5). For comparison, in a transect from the Sacramento River towards the Central Bay in the northern San Francisco Bay, Murrel et al. (1999) observed generally higher activity of amino peptidase in marine waters, and higher 
ß-glucosidase activity in river waters. Rates of hydrolysis estimated for the sites located along the Concepcion coast (this study) were comparable to those measured in northern San Francisco Bay. However, our rates of hydrolysis of protein for the Itata river were much lower than those measured by Karrasch et al. (2006) in the nearby Bio-Bío river, and within the range of those estimated for surface waters of the Ottawa, Maumee and Hudson rivers in north America (Sinsabaugh et al., 1997).

An increase in hydrolysis rates of MCA-leu, MUF-glu, and MUF-cel was observed in coastal waters during springsummer compared to winter (Fig. 5), probably associated with the enhancement of biological activity in marine waters reflected in an increase in the input of photosynthetic organic matter, as supported by the relation between EEA induced by MCA-leu, MUF-glu, and MUF-cel and chlorophyll- $a$ ( $p=0.00001,0.00004$, and 0.03 , respectively). Other studies reporting similar trends in hydrolysis along trophic gradients, such as for amino peptidase activity in the Caribbean Sea (Rath et al., 1993) and the Northern Adriatic Sea (Karner et al., 1992). However, organic matter supply may not be the only controlling factor of extracellular enzyme activity since the lack of a trend has also been observed between glucosidase activity and organic matter supply in the Northern Adriatic Sea (Karner et al., 1992).

Hydrolysis in surface sediments followed different patterns than those of the water column (Fig. 7), and was within the same order of magnitude as previous measurements in surface sediments in other coastal zones (e.g., Meyer-Reil, 1986, 1987; Mayer, 1989). Hydrolysis rates of MCA-leu, MUF-glu and MUF-cel were higher in the coastal and estuarine sediments than in river sediment during the entire study period. Here, hydrolysis of MCA-leu did not dominate, and even some of the fastest rates were those of MUFglu (Fig. 7). This difference between microbial enzyme activities in the water column and sediment is not unexpected since both environments might have different communities with different enzyme capabilities (Arnosti, 2008).

The temporal pattern in extracellular enzymatic hydrolysis in surface sediments was also different to that observed in seawater, and higher hydrolysis rates were observed during winter compared to spring-summer in coastal sediments (Figs. 6 and 7). This suggests that riverine transport of terrestrial organic matter may enhance hydrolysis during winter. In support of this hypothesis, we had previously observed dominance of particulate lithogenic opal over biogenic during austral winter in the coastal zone (Sánchez et al., 2008).

\subsection{Carbon fluxes in the coastal zone adjacent to the Itata River}

Using fluxes measured in this study and previous reports for primary productivity in the study area (Table 2), we produced a simple carbon budget for the coastal area adjacent to the Itata river discharge to determine whether our measured fluxes match those of the production of organic carbon. Additionally, we were also interested in estimating the potential capability of processing organic carbon as the input of allochthonous organics may increase as a consequence of increasing usage of the coastal area.

Depth integrated extracellular enzymatic hydrolysis rates ( $\Sigma$ MCA-leu + MUF-glu + MUF-cel) were estimated from the average of individual measurements collected during winter and spring-summer (Table 1) to generate average profiles of hydrolysis for the coastal zone. Sediment hydrolysis rates were at least three times lower than those of the water column amounting to $0.02 \pm 0.01$ and $0.02 \pm 0.02 \mathrm{~mol} \mathrm{C} \mathrm{m}^{-2} \mathrm{~d}^{-1}$ in winter and spring-summer, respectively. In the water column, integrated rates were higher, $0.06 \pm 0.01$ and $0.3 \pm 0.03 \mathrm{~mol} \mathrm{C} \mathrm{m}^{-2} \mathrm{~d}^{-1}$ in winter and spring-summer, respectively. The difference in hydrolysis between spring-summer and winter represents the excess hydrolysis between the two periods that we assume is independent of the concentration of substrate used for the incubation. Assuming that extracellular enzymatic hydrolysis responds mainly to the availability of organic matter, then " $\Delta$ hydrolysis" must reflect the increase in primary production between spring-summer and winter (" $\Delta$ primary production"). Thus, $\Delta$ hydrolysis for the water column was $0.3 \pm 0.03 \mathrm{~mol} \mathrm{C} \mathrm{m}^{-2} \mathrm{~d}^{-1}$ and null for surface sediments. Primary production in the study area ranged from 0 to $0.08 \mathrm{~mol} \mathrm{C} \mathrm{m}^{-2} \mathrm{~d}^{-1}$ during winter and 0.08 to $0.48 \mathrm{~mol} \mathrm{C} \mathrm{m}^{-2} \mathrm{~d}^{-1}$ during springsummer (Table 2), resulting in a $\Delta$ primary production of $0.3 \pm 0.2 \mathrm{~mol} \mathrm{C} \mathrm{m}^{-2} \mathrm{~d}^{-1}$. Our results showed a proportional increase of about $0.25 \mathrm{~mol} \mathrm{C} \mathrm{m}^{-2} \mathrm{~d}^{-1}$ in hydrolysis and primary production from austral winter to spring- summer. The magnitude of the increase of both fluxes was in the same order of magnitude suggesting a coupling between the synthesis of marine organic matter and the processing of organic polymers.

In conclusion, our study highlights the differences in hydrolytic activity in response to water column and surface sediment variability, and the potential importance of protein and carbohydrate hydrolysis in river waters, comparable to those of the marine coastal environment.

Acknowledgements. This research was funded by the Programa de Investigación Marina de Excelencia, PIMEX-Nueva Aldea (University of Concepción and Celulosa Arauco y Constitución S.A.). We also wish to thank Rodrigo Castro, Daniela Concha, Lilian Nuñez, and Jaime Soto from the Marine Organic Geochemistry laboratory at UDEC for their valuable help with analyses.

Edited by: G. Herndl 


\section{References}

Ahumada, R. and Chuecas, L.: Algunas características hidrográficas de la bahía de Concepción y áreas adyacentes, Chile, Gayana, 8, 1-56, 1979.

Albright, L. J.: Influence of river-ocean plumes upon bacterioplankton production of the Strait of Georgia, British Columbia, Mar. Ecol. Progr. Ser., 12, 107-113, 1983.

Arnosti, C.: Microbial Extracellular Enzymes and their Role in DOM Cycling, in: Aquatic Ecosystems: Interactivity of Dissolved Organic Matter, edited by: Findley, S. and Sinsabaugh, R. S., Academic Press, 315-342, 2003.

Arnosti, C.: Functional differences between Arctic sedimentary and seawater microbial communities: contrasts in microbial hydrolysis of complex substrates, FEMS Microbiol. Ecol., 66, 343-51, 2008.

Arnosti, C.: Microbial Extracellular Enzymes and the Marine Carbon Cycle, Ann. Rev. Mar. Sci., 3, 401-425, 2011.

Azam, F.: Microbial control of oceanic carbon flux: The plot thickens, Science, 280, 694-706, 1998.

Berner, R. A.: Early Diagenesis. A Theoretical Approach, Princeton University Press, 256 pp., 1980

Cai, W. J.: Estuarine and coastal ocean carbon paradox: $\mathrm{CO}_{2}$ sinks or sites of terrestrial carbon incineration?, Annu. Rev. Mar. Sci., 3, 123-145, 2011.

Cauwet, G.: DOM in the Coastal Zone, in: Biogeochemistry of Marine Dissolved Organic Matter, edited by: Hansell, D. A. and Carlson, C. A., Academic Press, San Diego, 579-609, 2002.

Chróst, R. J.: Environmental Control of the Synthesis and Activity of Aquatic Microbial Ectoenzymes, in: Microbial Enzymes in Aquatic Environments, edited by: Chróst, R. J., Springer, New York, 29-59, 1991.

Chróst, R. J. and Siuda, W.: Microbial production, utilization, and enzymatic degradation of organic matter in the upper trophogenic layer in the pelagial zone of lakes along a eutrophication gradient, Limnol. Oceanogr., 51, 749-762, 2006.

Daneri, G., Dellarossa, V., Quiñones, R., Jacob, B., Montero, P., and Ulloa, O.: Primary production and community respiration in the Humboldt current system off Chile and associated oceanic areas, Mar. Ecol. Progr. Ser., 197, 41-49, 2000.

Dussailant, A.: Hidrología de la Cuenca del Río Itata, in: La Cuenca Hidrográfica del Río Itata, edited by: Parra, O., Castilla, J. C., Romero, H., Quiñones, R., and Camaño, A., Editorial Universidad de Concepción, Chile, 27-43, 2009.

Figueroa, D. and Moffat, C.: On the influence of topography in the induction of coastal upwelling along the Chilean coast, Geophys. Res. Lett., 27, 3905-3908, 2000.

González, H. E., Menschel, E., Aparicio, C., and Barría, C.: Spatial and temporal variability of microplankton and detritus, and their export to the shelf sediments in the upwelling area off Concepción, Chile $\left(\sim 36^{\circ}\right.$ S), during 2002-2005, Progr. in Oceanogr., 75, 435-451, 2007.

Gutiérrez, M. H., Pantoja, S., Tejos, E., and Quiñones, R. A.: The role of fungi in processing marine organic matter in the upwelling ecosystem off Chile, Mar. Biol., 158, 205-219, 2011.

Hedges, J. I.: Global geochemical cycles: progress and problems, Mar. Chem., 39, 67-93, 1992.
Hedges, J. I.: Why Dissolved Organics Matter? in: Biogeochemistry of Marine Dissolved Organic Matter, edited by: Hansell, D. and Carlson, C. A., Academic Press, San Diego, 1-27, 2002.

Hedges, J. I. and Parker, P. L.: Land-derived organic matter in surface sediments from the Gulf of Mexico, Geochim. Cosmochim. Acta, 40, 1019-1029, 1976.

Hedges, J. I. and Keil, R. G.: Sedimentary organic matter preservation: an assessment and speculative synthesis, Mar. Chem., 49, 81-115, 1995.

Hoppe, H.-G.: Significance of exoenzymatic activities in the ecology of brackish water: measurements by means of methylumbelliferyl-substrates, Mar. Ecol. Progr. Ser. 11, 299308, 1983.

Hoppe, H.-G.: Microbial extracellular enzyme activity: a new key parameter in aquatic ecology, in: Microbial Enzymes in Aquatic Environments, edited by: Chróst, R. J., Springer, New York, 6083, 1991.

Karner, M., Fuks, D., and Herndl, G. J.: Bacterial activity along a trophic gradient, Microb. Ecol., 24, 243-257, 1992.

Karrasch, B., Parra, O., Cid, H., Mehrens, M., Pacheco, P., Urrutia, R., Valdovinos, C., and Zaror, C.: Effects of pulp and paper mill effluents on the microplankton and microbial self-purification capabilities of the Biobío River, Chile, Sci. Total Environ., 359, 194-208, 2006.

King, G.: Characterization of B-glucosidase activity in intertidal marine sediments, Appl. Environ. Microbiol., 51, 373-380, 1986.

Kirchman, D., Soto, D., Van Wambeke, F., and Bianchi, M.: Bacterial production in the Rhone River plume: Effect of mixing on relationships among microbial assemblages, Mar. Ecol. Progr. Ser., 53, 267-275, 1989.

Lee, C., Wakeham, S. G., and Arnosti, C.: Particulate organic matter in the sea: the composition conundrum, Ambio 33, 565-575, 2004.

Liu, K.-K., Atkinson, L., Chen, C. T. A., Gao, S., Hall, J., Macdonald, R. W., Talaue McManus, L., and Quiñones, R. A.: Exploring continental margin carbon fluxes on a global scale, EOS, Transactions, American Geophysical Union, 81, 641-644, 2000.

Mayer, L. M.: Proteolytic Enzyme Activity in Sediments of an Intertidal Mudflat, Limonol. Oceanogr., 34, 973-981, 1989.

Meyer-Reil, L.-A.: Measurement of hydrolytic activity and incorporation of dissolved organic substrates by microorganisms in marine sediments, Mar. Ecol. Prog. Ser. 31, 143-49, 1986.

Meyer-Reil, L.-A.: Seasonal and spatial distribution of extracellular enzymatic activities and microbial incorporation of dissolved organic substrates in marine sediments, Appl. Environ. Microbiol., 53, 1748-1755, 1987.

Myklestad, S. M. and Børsheim, K. Y.: Dynamics of carbohydrates in the Norwegian Sea inferred from monthly profiles collected during 3 years at $66^{\circ} \mathrm{N}, 2^{\circ} \mathrm{E}$, Mar. Chem., 107, 475-485, 2007.

Misic, C. and Fabiano, M.: Ectoenzymatic activity and its relationship to chlorophyll- $a$ and bacteria in the Gulf of Genoa (Ligurian Sea, NW Mediterranean), J. Mar. Sys., 60, 193-206, 2006.

Montero, P., Daneri, G., Cuevas, L. A., González, H. E., Jacob, B., Lizárraga, L., and Menschel, E.: Productivity cycles in the coastal upwelling area off Concepción: the importance of diatoms and bacterioplankton in the organic carbon flux, Progr. Oceanogr. 75, 518-530, 2007. 
Mopper, K. and Lindroth, P.: Diel and depth variations in dissolved free amino acids and ammonium in the Baltic Sea determined by shipboard HPLC analyses, Limnol. Oceanogr., 27, 336-347, 1982.

Muller-Karger, F. E., Varela, R., Thunell, R., Luerssen, R., Hu, C., and Walsh, J. J.: The importance of continental margins in the global carbon cycle, Geophys. Res. Lett., 32, L01602, doi:10.1029/2004g1021346, 2005.

Murrell, M. C., Hollibaugh, J. T., Silver, M. W., and Wong, P. S.: Bacterioplankton Dynamics in northern San Francisco Bay: role of particle association and seasonal freshwater flow, Limnol. Oceanogr., 44, 295-308, 1999.

Pakulski, J. D. and Benner, R.: Abundance and distribution of carbohydrates in the ocean, Limnol. Oceanogr., 39, 930-940, 1994.

Pantoja, S. and Lee, C.: Cell-surface oxidation of amino acids in seawater, Limnol. Oceanogr., 39, 1718-1726, 1994.

Pantoja, S., Lee, C., and Marecek, J. F.: Hydrolysis of peptides in seawater and sediment, Mar. Chem., 57, 25-40, 1997.

Pantoja, S., Rossel, P., Castro, R., Cuevas, L. A., Daneri, G., and Córdova, C.: Microbial degradation rates of small peptides and amino acids in the oxygen minimum zone of Chilean coastal waters, Deep-Sea Res. Pt. II, 56, 1019-1026, 2009.

Parsons, T., Maita, Y., and Lalli, C.: A Manual of Chemical and Biological Method for Seawater Analysis, Pergamon Press, Oxford, 173 pp., 1984.

Poretsky, R. S., Sun, S., Mou, X., and Moran, M. A.: Transporter genes expressed by coastal bacterioplankton in response to dissolved organic carbon, Environ. Microb., 12, 616-27, 2009.

Quiñones, R. A., Gutiérrez, M. H., Daneri, G., Gutiérrez, D., González, H. E., and Chavez, F.: The Humboldt Current System, in: Carbon and Nutrient Fluxes in Continental Margins, edited by: Liu, K. K., Atkinson, L., Quiñones, R., and TalaueMcManus, L., Springer, Germany, 44-64, 2010.

Rabouille, C., Mackenzie, F. T., and Ver, L. M.: Influence of the human perturbation on carbon, nitrogen, and oxygen biogeochemical cycles in the global coastal ocean, Geochim. Cosmochim. Acta, 65, 3615-3641, 2001.
Rath, J., Schiller, C., and Herndl, G. J.: Ectoenzymatic activity and bacterial dynamics along a trophic gradient in the Caribbean Sea, Mar. Ecol. Prog. Ser., 102, 89-96, 1993.

Sánchez, G. E., Pantoja, S., Lange, C. B., Gonzalez, H. E., and Daneri, G.: Seasonal changes in particulate biogenic and lithogenic silica in the upwelling system off Concepcion $\left(36^{\circ} \mathrm{S}\right)$, Chile, and their relationship to fluctuations in marine productivity and continental input, Cont. Shelf Res., 28, 2594-2600, 2008.

Schlitzer, R.: Ocean Data View, http://odv.awi.de, 2010.

Schubert, C. J, Ferdelman, T. G., and Strotmann, B.: Organic matter composition and sulfate reduction rates in sediment off Chile, Org. Geochem., 31, 351-361, 2000.

Sinsabaugh, R. L., Findlay, S., Franchini, P., and Fischer, D.: Enzymatic analysis of riverine bacterioplankton production, Limnol. Oceanogr., 42, 29-38, 1997.

Sobarzo, M., Bravo, L., Donoso, D., Garcés-Vargas, J., and Schneider, W.: Coastal upwelling and seasonal cycles that influence the water column over the continental shelf off central Chile, Progr. Oceanogr., 75, 363-382, 2007.

Strickland, J. D. H.: Measuring the Production of Marine Phytoplankton, Fisheries Research Board of Canada 172 pp., 1960.

Strickland, J. D. H. and Parsons, T. R.: A Practical Handbook of Seawater Analysis, Fisheries Research Board of Canada, Edn. 2, 310 pp., 1972.

Strub, P. T., Mesías, J. M., Montecino, V., Rutllant, J., and Salinas, S.: Coastal Ocean Circulation off Western South America. Coastal Segment (6,E), in: The Sea, edited by: Robinson, A. R. and Brink, K. H., John Wiley and Sons, NY, 273-308, 1998.

Ver, L. M. B., Mackenzie, F. T., and Lerman, A.: Carbon cycle in the coastal zone: Effects of global perturbations and change in the past three centuries, Chem. Geol., 159, 283-304, 1999. 